\title{
EVALUATION OF THE EFFECTIVENESS OF ACTIONS FOR THE BENEFIT OF PERSONS OF NON-MOBILE AGE IN EUROPEAN UNION COUNTRIES
}

\author{
Urszula Załuska, Dorota Kwiatkowska-Ciotucha \\ Wrocław University of Economics, Wrocław, Poland \\ e-mails: urszula.zaluska@ue.wroc.pl; dorota.kwiatkowska@ue.wroc.pl \\ (C) 2018 Urszula Załuska, Dorota Kwiatkowska-Ciotucha \\ This is an open access article distributed under the Creative Commons Attribution-NonCommercial- \\ -NoDerivs license (http://creativecommons.org/licenses/by-nc-nd/3.0/)
}

DOI: 10.15611/eada.2018.2.02

JEL Classification: C19

\begin{abstract}
The purpose of the paper is to assess the effectiveness of the applied solutions in individual EU countries in terms of supporting non-mobile people. Demographic aging affects most EU countries. It results in an increase in the number and proportion of older people and an increasing share of the post-working population. In such conditions, it is very important to maintain the activity on the labor market of people in the so-called non-mobile age. Maintaining professional activity depends on a number of factors, including, first and foremost, the assurance of openness in the labor market, adequate financial standing and medical care, and the ability to develop competencies and keep pace with technological change. This requires, on the one hand, the application of appropriate policies to this group and, on the other, the possibilities of the country. The study compared the situation of people in the indicated age group with the situation of the general population at working age.
\end{abstract}

Keywords: non-mobile age, taxonomic methods, comparison of EU countries.

\section{Introduction}

The purpose of the article is to assess the situation of people of non-mobile age in EU countries against the situation of people of working age. People of non-mobile age are those aged 50-64 or 45-64. The differences result from the ambiguous definition of this group in the literature of the subject.

The increasing gravity of older generations in EU countries for their economies was the inspiration to undertake research into the assessment of the situation of people of non-mobile age in the Member States and to compare it with the situation of the general population of working age. The aging process has led to an increase in the number and proportion of older people. The median age in EU countries has increased by six years between 1990 and 2012. On average, in the EU as many as $44 \%$ of the working-age population of non-mobile age [Kryńska, Szukalski (eds.) 
2013, p. 21]. This situation requires a proper policy to maintain the professional activity of people in this age group.

There are numerous factors which determine the effectiveness of professional activity in the case of older people. The most important are: the openness of the labour market to persons of older age groups, appropriate financial situation, adequate medical care and opportunities for the development of competencies and keeping pace with technological progress. Against this background, the question arises whether the key to success are financial issues. In other words, does the overall situation in the country translate into the situation of people of non-mobile age? Are there countries where the situation of people of non-mobile age is significantly different from that of all working-age persons?

In this article, the authors analyse the results of research where two approaches were employed to assess the situation of the above-mentioned groups. The first approach is based on objective data that illustrates the situation in areas of particular social importance, namely the labour market, the financial situation, health and medical care, as well as education and the use of modern technologies. The second approach uses subjective satisfaction assessments. The study employed taxonomic methods ${ }^{1}$.

\section{The research material and analytical tools used during the research}

The analysis was based on the latest data from the Eurostat database (as of July 2017). For an objective assessment of the situation in individual countries, 12 variables characterising the four areas were used (see Table 1). Due to the availability, for the group of persons of non-mobile age, data pertaining to various age groups was used. In the approach using objective data, each of the distinguished areas was characterised by two to four variables. The variables used in the study were stimuli (S -7 variables) or destimuli ${ }^{2}$ ( $\mathrm{D}-5$ variables). All variables differentiate the surveyed population, with the highest variability being the variable $x_{8}$-the proportion of people unhappy with healthcare (coefficient of variation at level $102 \%$ ), with the smallest variable being $x_{1}$ - the employment rate (13\%).

The second approach to evaluating the situation in individual EU countries was based on the use of the perception of individual satisfaction. In this subjective approach, out of the defined areas of satisfaction assessment four partial indicators: satisfaction with the financial situation, satisfaction with housing conditions,

${ }^{1}$ More on taxonomy methods among others in: [Hellwig 1968; 1981; Borys 1978; Grabiński, Wydymus, Zeliaś 1989; Kurkiewicz, Pociecha, Zając 1991; Grabiński 1992; Walesiak 1996; Gatnar, Walesiak 2004; Panek 2009].

${ }^{2}$ Stimuli are variables whose value increase is desirable; destimuli, on the other hand, are variables whose value decrease is desirable. More on the interpretation of characteristics in: [Strahl 1990; Borys 1978]. 
Table 1. Component indicators

\begin{tabular}{|c|c|c|c|c|}
\hline Variable & Description & Year & Age for NM & Nature \\
\hline \multicolumn{5}{|c|}{ Labour market (LM) } \\
\hline$x_{1}$ & Employment rate [\%] & 2016 & $50-64$ & $\mathrm{~S}$ \\
\hline$x_{2}$ & Unemployment rate [\%] & 2016 & $50-64$ & $\mathrm{D}$ \\
\hline$x_{3}$ & Long-term unemployment [\%] & 2016 & $50-64$ & $\mathrm{D}$ \\
\hline \multicolumn{5}{|c|}{ Financial situation (FS) } \\
\hline$x_{4}$ & Mean hourly earnings in PPS & 2014 & $50-59$ & $\mathrm{~S}$ \\
\hline$x_{5}$ & Low-wage earners as a proportion of all employees [\%] & 2014 & $50-64$ & $\mathrm{D}$ \\
\hline \multicolumn{5}{|c|}{ Health and medical care (H\&MC) } \\
\hline$x_{6}$ & Self-perceived health: good or very good [\%] & 2015 & $45-64$ & $\mathrm{~S}$ \\
\hline$x_{7}$ & People having a long-standing illness or health problem [\%] & 2015 & $45-64$ & $\mathrm{D}$ \\
\hline$x_{8}$ & Self-reported unmet needs for medical examination [\%] & 2015 & $45-64$ & $\mathrm{D}$ \\
\hline \multicolumn{5}{|c|}{ Education and ICT use (E\&ICT) } \\
\hline$x_{9}$ & Population by higher education [\%] & 2016 & $45-64$ & $\mathrm{~S}$ \\
\hline$x_{10}$ & Participation rate in education and training (last 4 weeks) [\%] & 2016 & $55-64$ & $\mathrm{~S}$ \\
\hline$x_{11}$ & Computer use last 12 months [\%] & 2015 & $55-64$ & $\mathrm{~S}$ \\
\hline$x_{12}$ & Internet use last 3 months [\%] & 2016 & $55-64$ & $\mathrm{~S}$ \\
\hline
\end{tabular}

$\mathrm{NM}$ - non-mobile age group.

Source: own elaboration based on Eurostat database.

satisfaction with work and satisfaction with the use of time, were used. The variable satisfaction is presented in the Eurostat database as the percentage of responses to one of three variants of assessment: "high", "medium" and "low." The study considered the differences between the percentage of responses estimating satisfaction as "high" and those who responded with "low". It is assumed that this is the most complete way for the subjective assessment of the situation in individual countries. The values obtained due to such calculations illustrate an excess of people evaluating their satisfaction as high over those who estimate their satisfaction level as low (a positive result), or vice versa, the excess of people who rated their satisfaction as low versus those highly satisfied (a negative result).

In order to compare objects in multidimensional space, taxonomic methods were employed in the study. Two methods of linear ordering were used, namely the composite indicator method [Grabiński 1992; Strahl 1990; Kwiatkowska-Ciotucha, 2002; Załuska 2002] for assessing the situation based on objective data, and the development pattern method [Hellwig 1968] to assess the situation based on subjective data.

When constructing a composite indicator, the following assumptions were made:

- component indicators used to construct the composite indicator differentiate the surveyed population, 
- component indicators do not replicate the transmitted information,

- the standardisation procedure of the component indicators leads to the conversion of their original values into the interval $[0 ; 1]$,

- all component indicators have the same meaning for the evaluation of the situation,

- the composite indicator is a normalized stimuli with the values within the interval $[0 ; 1]$.

For component indicators with a stimuli character, normalization to the maximum values observed in the sample was applied. For destimuli, normalization to the minimum values observed in the sample was used. The composite indicator $Z$ was calculated as the arithmetic mean of the normalized component indicators (see Formulas 1-3).

$$
\begin{aligned}
& \text { Stimuli Destimuli Composite indicators } \\
& z_{i j}=\frac{x_{i j}}{\max _{j} x_{i j}} \text { (1) } \quad z_{i j}=\frac{\min _{j} x_{i j}}{x_{i j}} \text { (2) } \quad Z_{i}=\frac{1}{m} \sum_{j=1}^{m} z_{i j}
\end{aligned}
$$

where: $Z_{i}-$ component indicator for $i$-country,

$z_{i j}$ - normalized value of component variable for $i$-country,

$j$-number of component indicators $(j=1, \ldots, m)$.

Due to the lack of prerequisites, the simplest solution for component variables weighing was used i.e. equal weights were used for composite indicator construction. On the basis of the normalized values of the component indicators, five composite indicators were created in total and separately for each of the research areas.

To assess the situation in the approach based on subjective feelings of satisfaction, the method of Hellwig's development pattern was applied [Hellwig 1968]. Normalised (standardized) values of variables which possess the stimuli nature are used. The algorithm of the method includes:

1. Development pattern is constructed. This is an abstract multidimensional point containing the "best" values for each variable.

Development pattern: $\quad \mathbf{z}_{\mathbf{0}}=\left[\begin{array}{llll}\mathrm{z}_{01} & \mathrm{z}_{02} & \cdots & \mathrm{z}_{0 \mathrm{~m}}\end{array}\right]$

$$
\begin{gathered}
z_{0 j}=\max _{i} z_{i j}, \text { for stimuli, } \\
z_{0 j}=\min _{i} z_{i j}, \text { for destimuli. }
\end{gathered}
$$

2. Analogously, the so-called anti-pattern of development with the "worst" values for each variable is established.

Anti-pattern:

$$
\begin{aligned}
\mathbf{z}_{-0}=\left[\mathrm{z}_{-01} \mathrm{z}_{-02} \ldots \mathrm{z}_{-0 \mathrm{~m}}\right] \\
z_{0 j}=\min _{i} z_{i j}, \text { for stimuli, }
\end{aligned}
$$




$$
z_{0 j}=\max _{i} z_{i j} \text {, for destimuli. }
$$

3. The similarity of the observation to the abstract "best" observation was measured by calculating the Euclidean distance of each observation from the development pattern:

$$
d_{i 0}=\sqrt{\sum_{j=1}^{m}\left(z_{j}-z_{0 j}\right)^{2}} \quad i=1,2, \ldots, n .
$$

4. So-called development measures were calculated for each observation (country) according to the formula:

$$
m_{i}=1-\frac{d_{i 0}}{d_{0}} \quad i=1,2, \ldots, n,
$$

where: $m_{i}-$ development measure for $i$-country,

$d_{0}$ - Euclidean distance between development pattern and anti-pattern

$$
d_{0}=\sqrt{\sum_{j=1}^{m}\left(z_{0 j}-z_{-0 j}\right)^{2}} .
$$

\section{Discussing research results}

Countries were ordered in accordance with the composite indicator values, starting with the most friendly towards non mobile population (highest value of composite indicator), with the least friendly towards non mobile population (lowest value of composite indicator). In Table 2 the results of rankings based on composite indicators for the total population of people of working age (Total $-\mathrm{T})$ and for non - mobile (Non mobile age - NM) were shown.

In Figure $1 \mathrm{a}$ correlation chart between the values of the composite indicator for all working-age persons and for non-mobile persons is presented. As one may see from the scattered points, the relative situation in both groups is very similar. The highest values in both cases were obtained for Sweden, the lowest for Portugal. In Figure 1, Poland and Germany were also pinpointed - ninth place for Germany for both groups and $19^{\text {th }}$ and $21^{\text {st }}$ places for Poland for total and the non-mobile group respectively. The positions of selected countries based on rankings built on objective data will be discussed later in this article with rankings based on the subjective satisfaction of the respondents.

In Figure 2 the differences between the position of the country regarding the situation of the general population of working age and the position of the country concerning the situation of persons of non-mobile age is presented. Positive values indicate a higher position of the country as perceived by persons of non-mobile age, 
Evaluation of the effectiveness of actions for the benefit of persons of non-mobile age...

Table 2. Rank for total (T) and non-mobile age group (NM)

\begin{tabular}{|c|c|c|c|c|c|c|c|c|c|c|c|c|}
\hline \multirow{2}{*}{ Country } & \multicolumn{2}{|c|}{ General $Z_{\mathrm{i}}$} & \multicolumn{2}{|c|}{ LM } & \multicolumn{2}{|c|}{ FS } & \multicolumn{2}{|c|}{ H\&MC } & \multicolumn{2}{|c|}{ E\&ICT } & \multicolumn{2}{|c|}{ Satisfaction } \\
\hline & $\mathrm{T}$ & NM & $\mathrm{T}$ & NM & $\mathrm{T}$ & NM & $\mathrm{T}$ & NM & $\mathrm{T}$ & NM & $\mathrm{T}$ & NM \\
\hline 1 & 2 & 3 & 4 & 5 & 6 & 7 & 8 & 9 & 10 & 11 & 12 & 13 \\
\hline Austria & 5 & 7 & 7 & 10 & 11 & 11 & 2 & 2 & 9 & 11 & 3 & 5 \\
\hline Belgium & 7 & 6 & 18 & 18 & 2 & 2 & 7 & 9 & 10 & 10 & 7 & 7 \\
\hline Bulgaria & 26 & 24 & 20 & 20 & 26 & 27 & 8 & 6 & 26 & 26 & 27 & 27 \\
\hline Cyprus & 15 & 18 & 23 & 24 & 15 & 13 & 12 & 15 & 14 & 19 & 19 & 19 \\
\hline Czech Republic & 13 & 14 & 4 & 5 & 20 & 20 & 17 & 16 & 18 & 15 & 12 & 12 \\
\hline Denmark & 2 & 2 & 3 & 3 & 4 & 3 & 15 & 14 & 3 & 1 & 2 & 1 \\
\hline Estonia & 17 & 16 & 13 & 11 & 23 & 23 & 25 & 25 & 7 & 7 & 22 & 23 \\
\hline Finland & 6 & 8 & 12 & 12 & 3 & 7 & 21 & 21 & 2 & 3 & 1 & 2 \\
\hline France & 11 & 11 & 21 & 21 & 7 & 9 & 20 & 18 & 8 & 8 & 13 & 10 \\
\hline Germany & 9 & 9 & 5 & 4 & 9 & 8 & 18 & 19 & 13 & 9 & 18 & 18 \\
\hline Greece & 24 & 19 & 27 & 27 & 18 & 15 & 9 & 3 & 24 & 24 & 26 & 26 \\
\hline Hungary & 20 & 22 & 10 & 14 & 21 & 21 & 23 & 23 & 20 & 17 & 25 & 25 \\
\hline Ireland & 10 & 10 & 19 & 17 & 6 & 5 & 6 & 7 & 11 & 12 & 9 & 8 \\
\hline Italy & 18 & 12 & 25 & 19 & 8 & 10 & 14 & 5 & 25 & 20 & 21 & 20 \\
\hline Latvia & 25 & 23 & 16 & 13 & 25 & 25 & 27 & 27 & 16 & 13 & 23 & 22 \\
\hline Lithuania & 21 & 25 & 14 & 15 & 24 & 24 & 24 & 24 & 17 & 16 & 14 & 16 \\
\hline Luxembourg & 4 & 4 & 8 & 8 & 5 & 4 & 5 & 10 & 4 & 6 & 6 & 6 \\
\hline Malta & 12 & 13 & 6 & 6 & 14 & 16 & 10 & 13 & 21 & 21 & 10 & 11 \\
\hline Netherlands & 3 & 3 & 9 & 16 & 10 & 6 & 1 & 1 & 6 & 5 & 5 & 4 \\
\hline Poland & 19 & 21 & 11 & 9 & 19 & 19 & 22 & 22 & 23 & 25 & 11 & 13 \\
\hline Portugal & 27 & 27 & 24 & 25 & 17 & 17 & 26 & 26 & 19 & 23 & 24 & 24 \\
\hline Romania & 23 & 20 & 15 & 7 & 27 & 26 & 4 & 4 & 27 & 27 & 17 & 17 \\
\hline Slovakia & 22 & 26 & 22 & 23 & 22 & 22 & 16 & 20 & 22 & 22 & 15 & 14 \\
\hline Slovenia & 14 & 17 & 17 & 22 & 16 & 18 & 3 & 12 & 15 & 18 & 16 & 15 \\
\hline Spain & 16 & 15 & 26 & 26 & 13 & 14 & 11 & 11 & 12 & 14 & 20 & 21 \\
\hline Sweden & 1 & 1 & 1 & 2 & 1 & 1 & 13 & 8 & 1 & 2 & 4 & 3 \\
\hline United Kingdom & 8 & 5 & 2 & 1 & 12 & 12 & 19 & 17 & 5 & 4 & 8 & 9 \\
\hline
\end{tabular}

LM - labour market.

FS - financial situation.

$\mathrm{H} \& \mathrm{MC}$ - health and medical care.

E\&ICT - education and the use of information technologies.

Source: own calculation.

whereas negative values signal the opposite (compared with people of working age). The greatest differences in favour of persons of non-mobile age were observed in Italy (+6). In contrast, people in Lithuania and Slovakia estimated their situation as disadvantageous $(-4)$. 


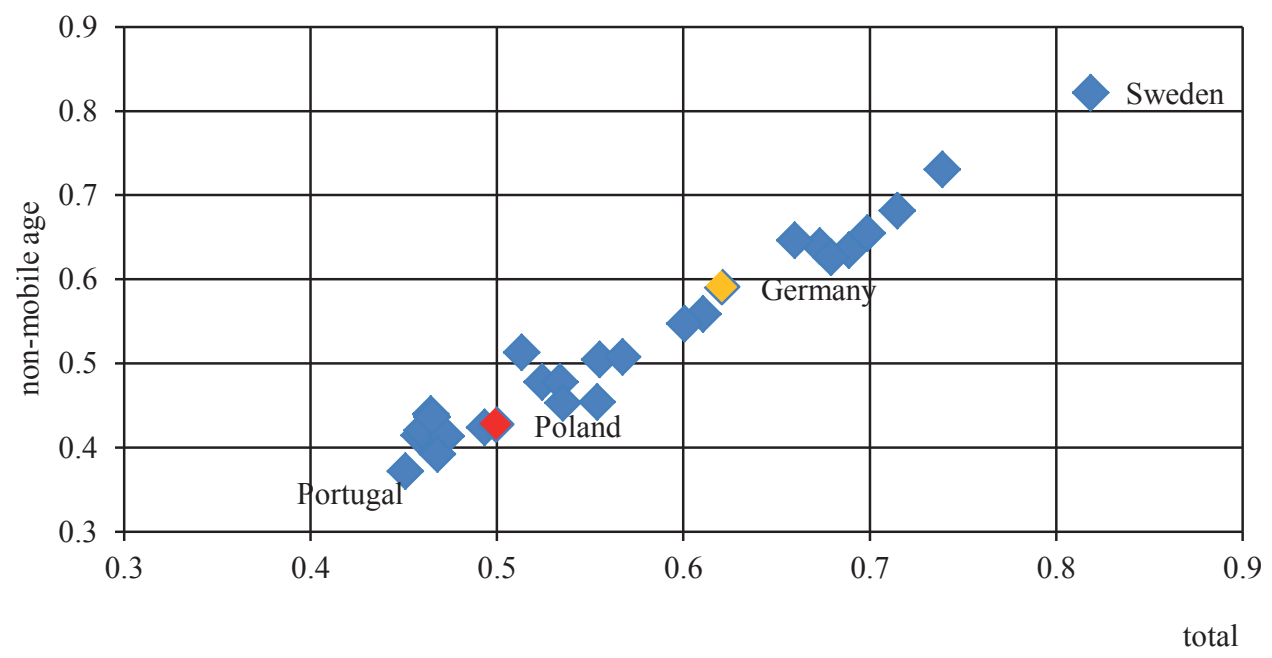

Fig. 1. General composite indicator - correlation chart between values describing total population and those for non-mobile age persons

Source: own calculation.

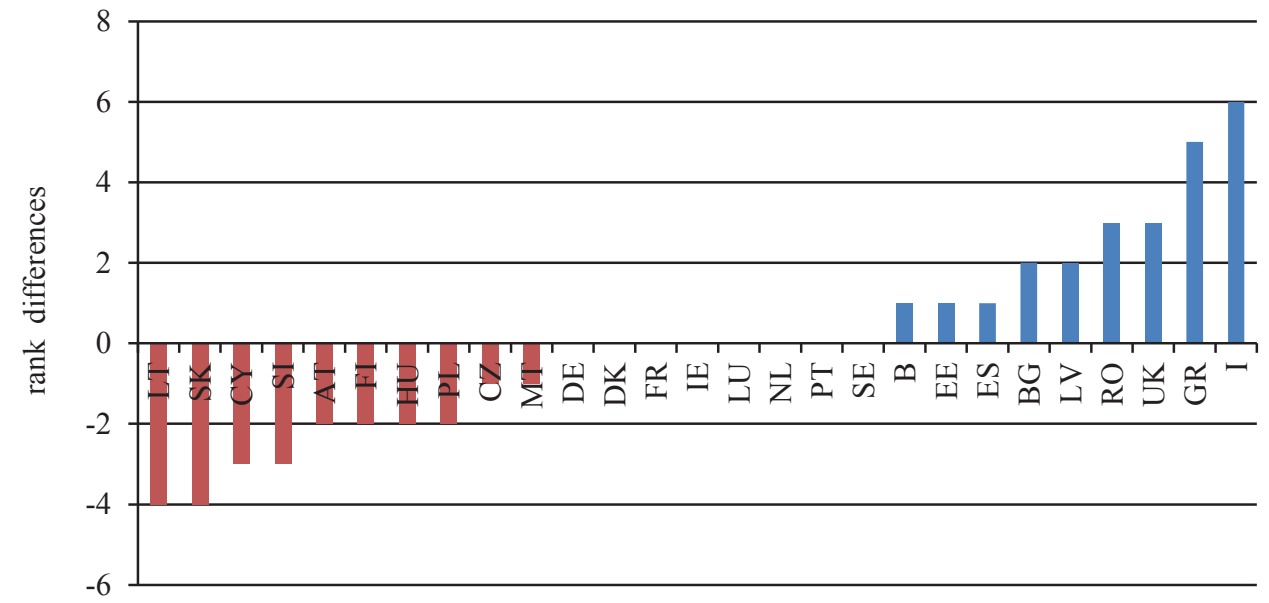

Fig. 2. General composite indicator - rank differences - total versus non-mobile age persons Source: own calculation.

In the labour market (see Figure 3 and Figure 4), the biggest differences in favour of the non-mobile population were observed in Romania (+8), and the opposite in the Netherlands (-7). The best assessment of the situation for both surveyed groups in the labour market area was observed in Sweden and the UK, the worst in Greece. 


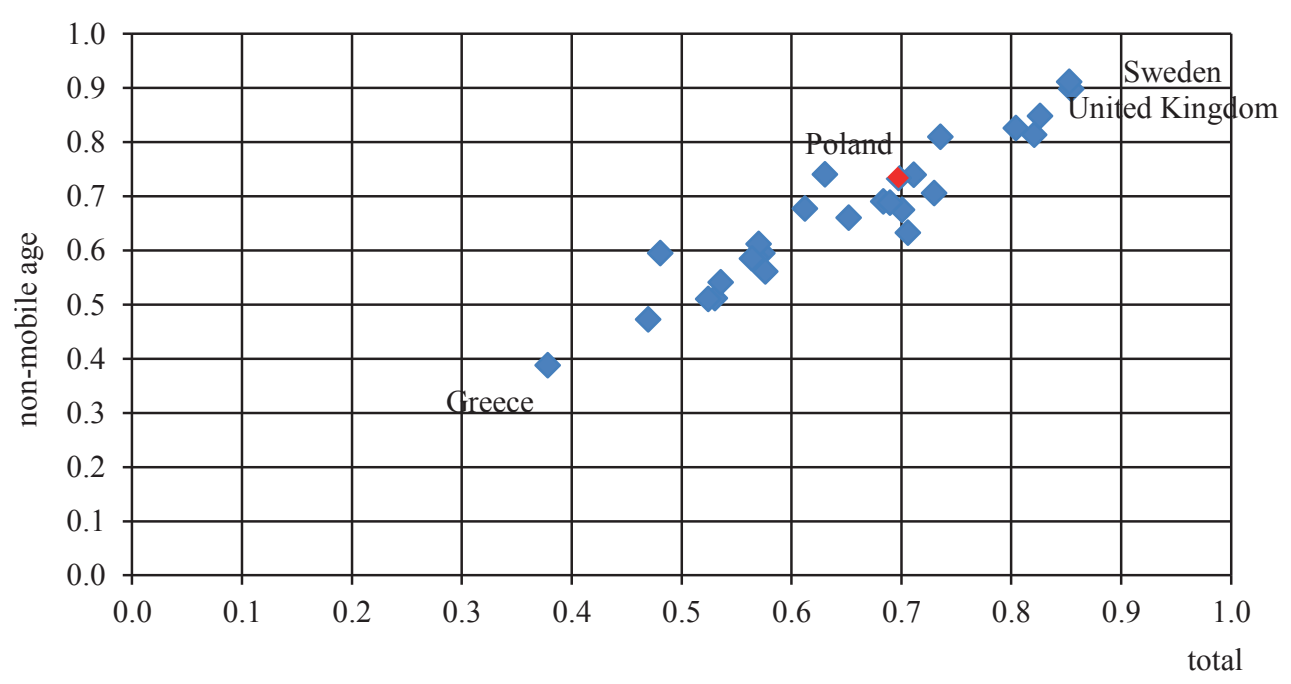

Fig. 3. Labour market area - correlation chart between total and non-mobile age persons Source: own calculation.

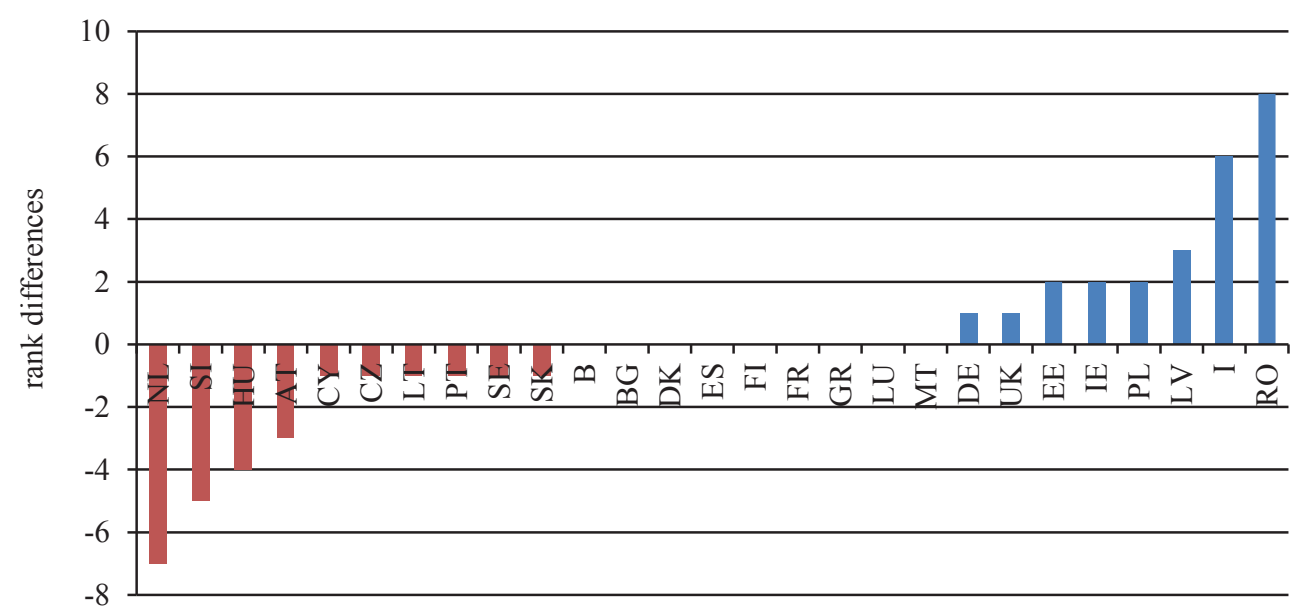

Fig. 4. Labour market area - rank differences total versus non-mobile age persons

Source: own calculation.

In the area of financial situation (see Figure 5 and Figure 6 ), the biggest differences in favour of persons of non-mobile age were observed in the Netherlands $(+4$ positions), while Finland was perceived as disadvantageous ( -4 positions). The first place for both groups was again claimed by Sweden, whereas the worst situation was observed in Bulgaria and Romania. 


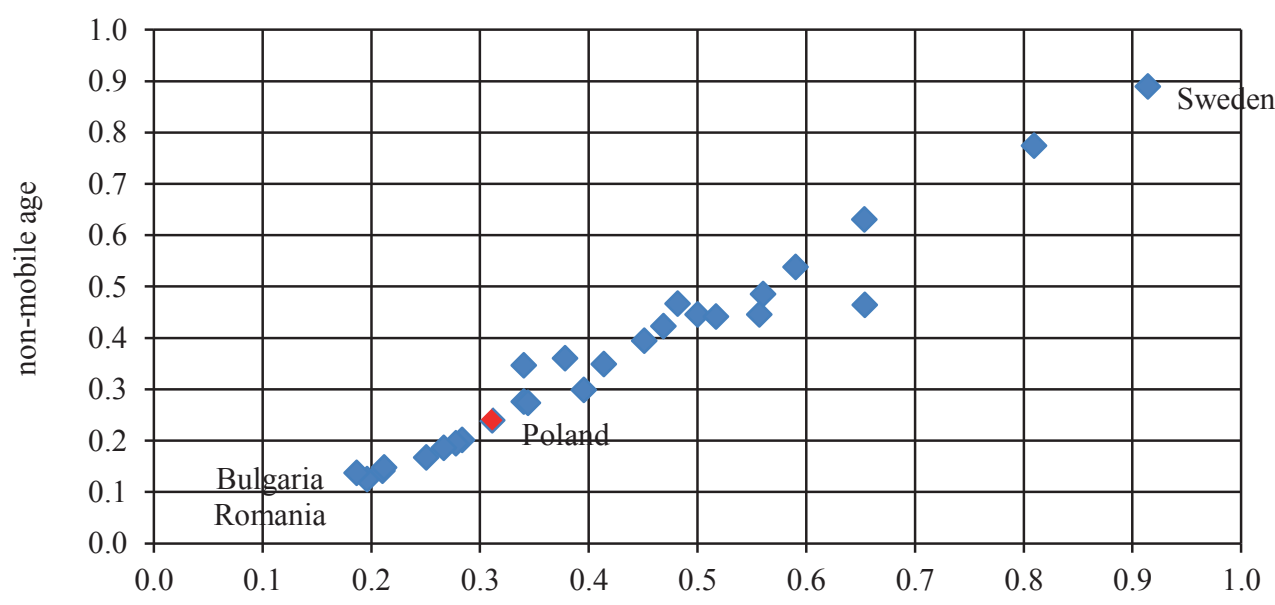

total

Fig. 5. Financial situation area - correlation chart between total and non-mobile age persons

Source: own calculation.

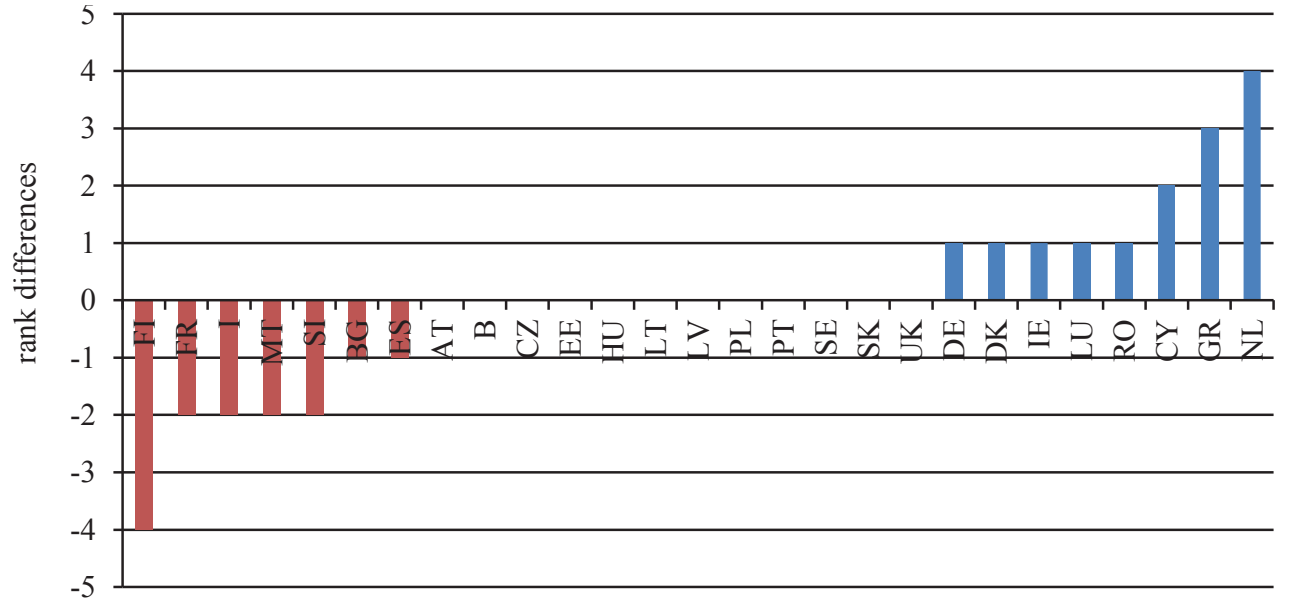

Fig. 6. Financial situation area - rank differences total versus non-mobile age persons

Source: own calculation.

In the field of health and medical care (see Figure 7 and Figure 8), the best situation for both groups was observed in the Netherlands and Austria, the worst in Estonia and Latvia. The biggest differences in favour of persons of non-mobile age were observed in Italy $(+9)$, whereas Slovenia was deemed the most disadvantageous ( -9 rank difference value). 


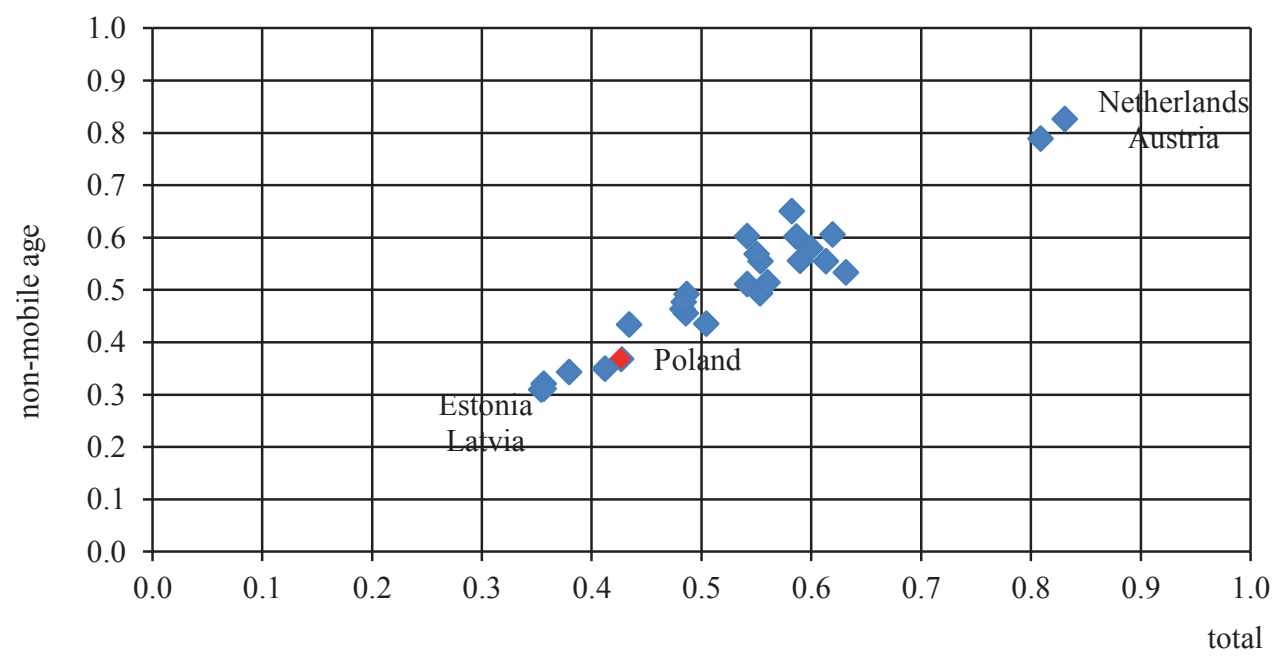

Fig. 7. Health and medical care area - correlation chart between total and non-mobile age persons Source: own calculation.

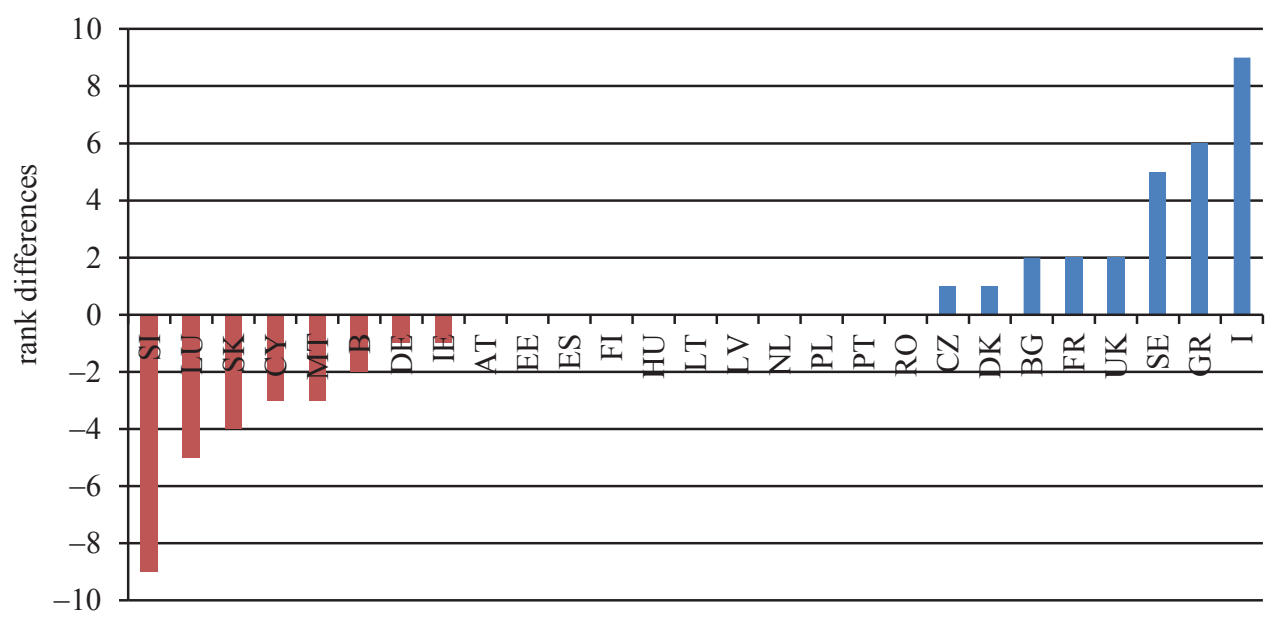

Fig. 8. Health and medical care area - rank differences total versus non-mobile age persons Source: own calculation.

In the area of education and ICT use (see Figure 9 and Figure 10), the best situation for both groups was observed in Scandinavia (Denmark, Sweden, Finland), the worst in Romania. The biggest difference in favour of persons of non-mobile age was once again observed in Italy ( +5 positions), with Cyprus being deemed the most disadvantageous ( -5 positions). 


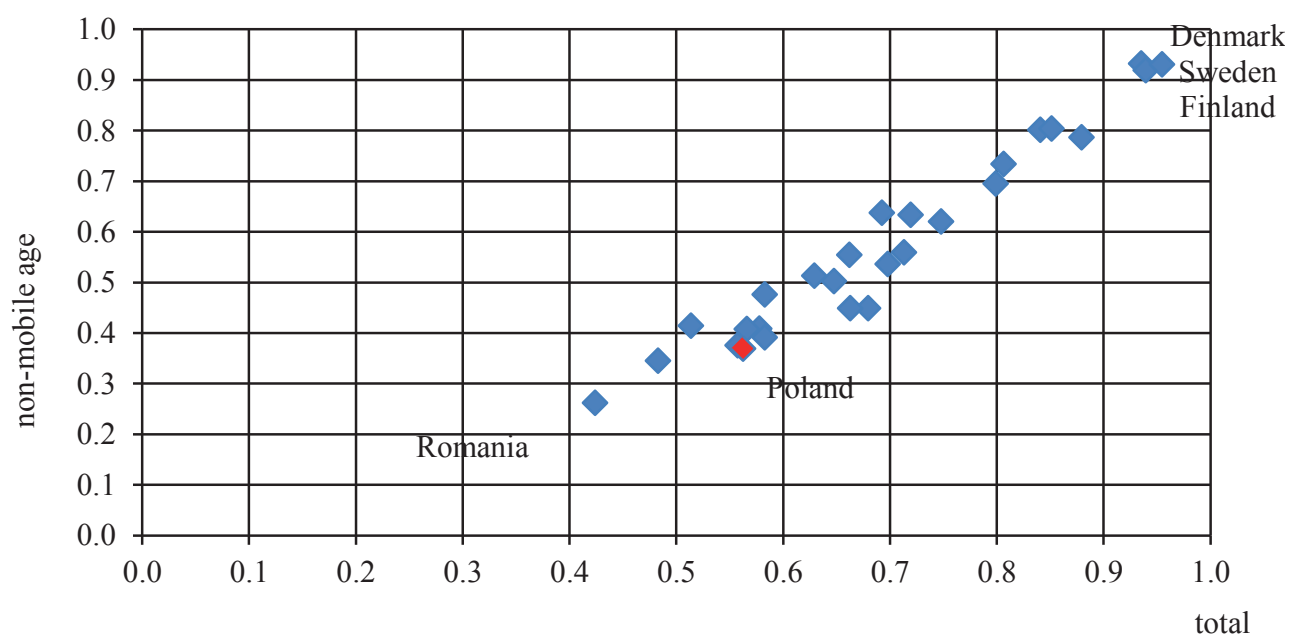

Fig. 9. Education and ICT use area - correlation chart between total and non-mobile age persons Source: own calculation.

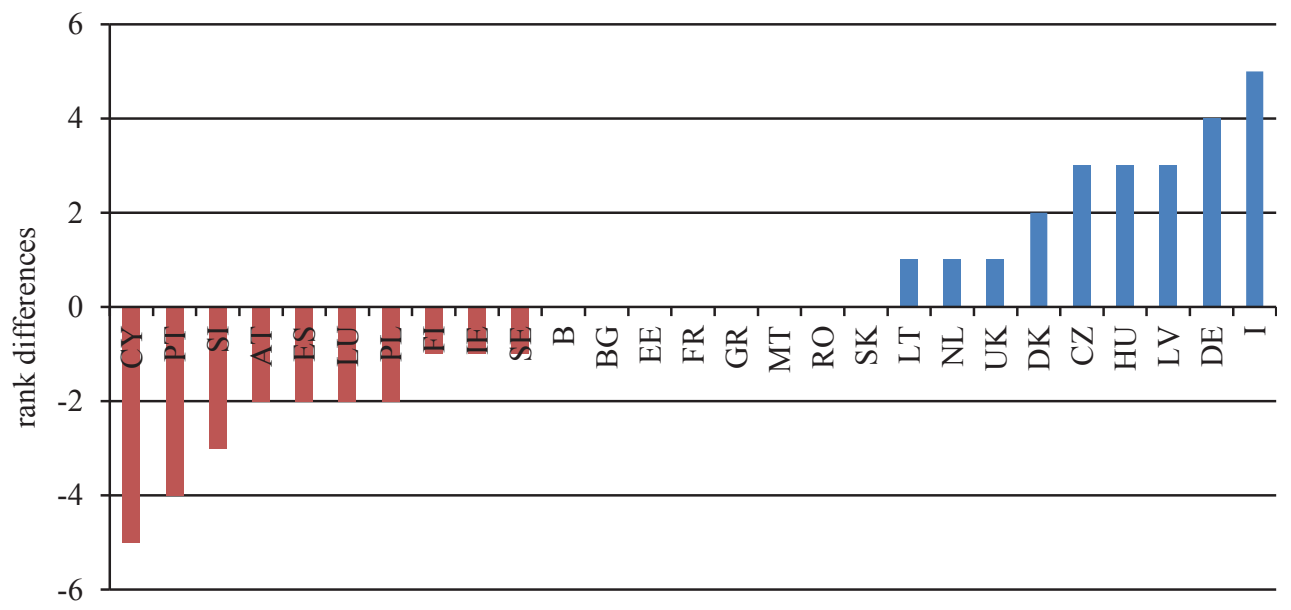

Fig. 10. Education and ICT use area - rank differences total versus non-mobile age persons Source: own calculation.

The measure of development is a stimuli, i.e. the more favourable level of a complex phenomenon, the higher the value of development measure.

In Figure 11 the correlation chart of the country-specific development measures in both research groups is presented. It is interesting to note the immense differentiation of value for the obtained development measure (from 0 to 0.999). According to the subjective opinions of the respondents, the best situation for people of non-mobile 


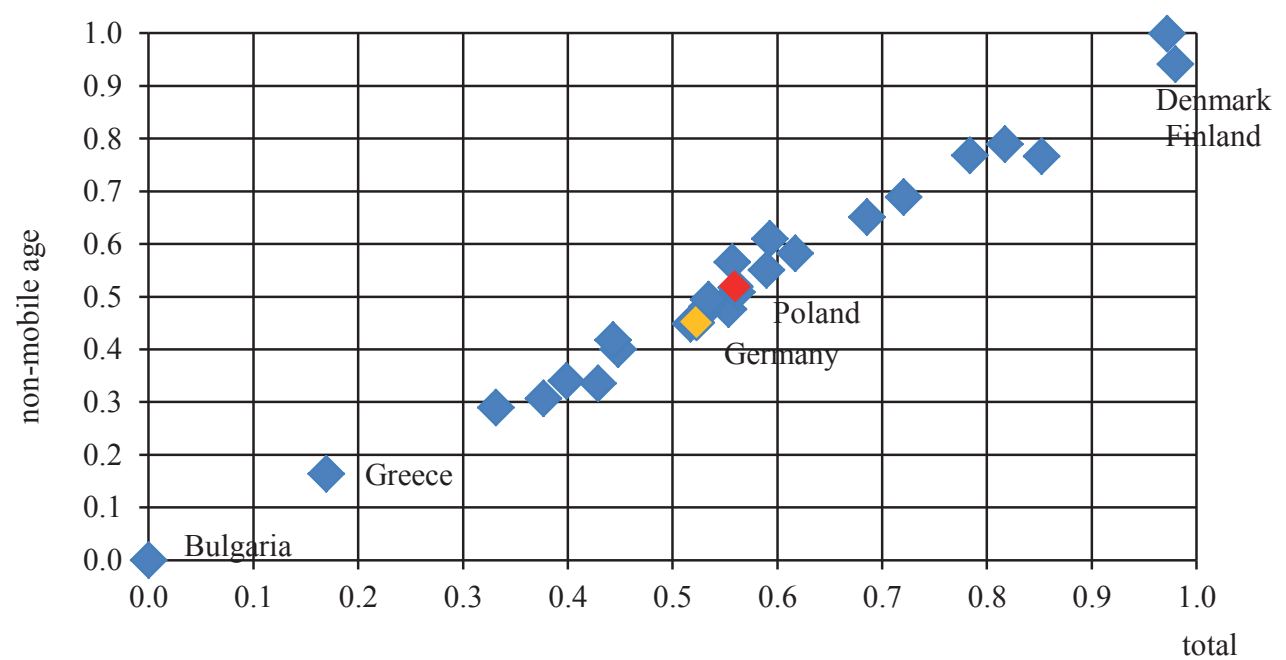

Fig. 11. Satisfaction - correlation chart between total and non-mobile age persons Source: own calculation.

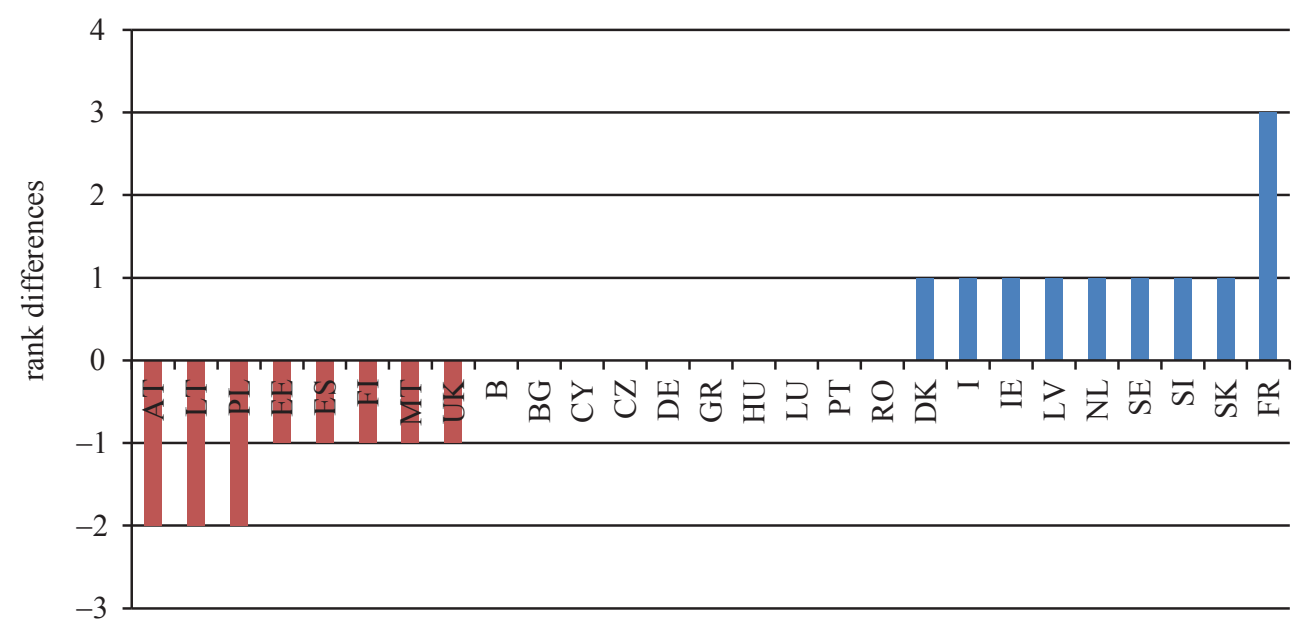

Fig. 12. Satisfaction - rank differences total versus non-mobile age persons

Source: own calculation.

age is found in Denmark (development measure at 0.999), and only slightly worse in Finland. On the other side there is Bulgaria (measure of development $0-$ in the position of anti-pattern). The low development measure for Germany is puzzling and it occurs for both studied groups $\left(18^{\text {th }}\right.$ place $)$. On the contrary, subjective 
assessments in Poland are relatively high, which placed it in both rankings in 12 places.

Table 2 shows the results of the rankings based on the measure of development for the whole population of people working (Total - T) and for non - mobile age (NM). In Figure 12 the differences in positions obtained by each country in the rankings according to the value of development measures for both analysed groups is illustrated. The differences in this case are less striking than those observed for composite indicators from the objective data. The biggest positive rank difference value for persons of non-mobile age were observed in France $(+3)$, and the highest negative rank difference values $(-2)$ for Poland, Austria and Lithuania.

\section{Concluding remarks}

To summarise the results of the research, it is worth emphasizing that the situation of persons of non-mobile age is strongly related to the situation of the general population of working age. This is evidenced by the very high values of the correlation coefficients.

It is important to note the exceptionally favourable situation in the Scandinavian countries for the working-age population, which also translates into the very positive situation of persons of non-mobile age. This is evident both in the assessment based on objective data (composite indicator) and subjective perceptions (development pattern).

The largest positive differences for persons of non-mobile age were observed in Italy.

Interesting insights were provided by the analysis of the results for Poland and Germany. According to the objective data, the situation in Germany is much more favourable for both analysed groups (rank 9) than it is in Poland (rank 20). On the other hand, in the subjective assessment, Poland was in $12^{\text {th }}$ place, while Germany in $18^{\text {th }}$. This means that Germans are much more critical than Poles in assessing their situation.

\section{Bibliography}

Borys T., 1978, Metody normowania cech w statystycznych badaniach porównawczych, Przegląd Statystyczny, no. 2, pp. 371-382.

Gatnar E., Walesiak M., 2004, Metody statystycznej analizy wielowymiarowej w badaniach marketingowych, Akademia Ekonomiczna Wrocław, Wrocław.

Grabiński T., 1992, Metody taksonometrii, Akademia Ekonomiczna w Krakowie, Kraków.

Grabiński T., Wydymus S., Zeliaś A., 1989], Metody taksonomii numerycznej w modelowaniu zjawisk społeczno-gospodarczych, PWN, Warszawa.

Hellwig Z., 1968, Zastosowanie metody taksonomicznej do typologicznego podziału krajów ze względu na poziom ich rozwoju oraz zasoby i strukturę wykwalifikowanych kadr, Przegląd Statystyczny, no. 4. 
Hellwig Z., 1981, Wielowymiarowa analiza porównawcza i jej zastosowanie w badaniach wielocechowych obiektów gospodarczych, [in:] Metody i modele ekonomiczno-matematyczne w doskonaleniu zarzadzania gospodarka socjalistyczna, Welfe W. (ed.), PWE, Warszawa.

Kryńska E., Szukalski P. (eds.), 2013, Rozwiązania sprzyjające aktywnemu starzeniu się w wybranych krajach Unii Europejskiej, Uniwersytet Łódzki, Łódź.

Kurkiewicz J., Pociecha J., Zając K., 1991, Metody wielowymiarowej analizy porównawczej w badaniach rozwoju demograficznego, Szkoła Główna Handlowa, Instytut Statystyki i Demografii, Monografie i Opracowania no. 336, Warszawa.

Kwiatkowska-Ciotucha D., 2002, Ranking branż produkcyjnych w Polsce w 2000, Ekonometria 9, pp. 198-208.

Panek T., 2009, Statystyczne metody wielowymiarowej analizy porównawczej, Szkoła Główna Handlowa, Warszawa.

Strahl D., 1990, Metody programowania rozwoju społeczno-gospodarczego, PWE, Warszawa.

Walesiak M., 1996, Metody analizy danych marketingowych, PWN, Warszawa.

Załuska U., 2002, Próba klasyfikacji polskiego sektora produkcyjnego, Ekonometria 9, pp. 209-216.

\section{OCENA SKUTECZNOŚCI DZIAŁAŃ NA RZECZ OSÓB W WIEKU NIEMOBILNYM W KRAJACH UNII EUROPEJSKIEJ}

Streszczenie: Celem artykułu jest ocena skuteczności rozwiązań stosowanych w poszczególnych krajach Unii w zakresie wspierania osób w wieku niemobilnym. Zjawisko demograficznego starzenia się społeczeństw dotyczy większości krajów UE. Jego skutkiem jest wzrost liczby i odsetka osób ze starszych grup wiekowych oraz coraz większy udział w ogóle ludności osób w wieku poprodukcyjnym. W takich uwarunkowaniach bardzo ważne jest utrzymanie aktywności na rynku pracy osób w tzw. wieku niemobilnym. Utrzymanie aktywności zawodowej zależy od wielu czynników, w tym głównie od zapewnienia: otwartości rynku pracy, odpowiedniej sytuacji finansowej i opieki medycznej, a także możliwości rozwoju kompetencji i nadążania za zachodzącymi zmianami technologicznymi. To wymaga, z jednej strony, stosowania odpowiednich polityk ukierunkowanych na tę grupę, z drugiej zaś wiąże się z możliwościami danego kraju. W ramach badań porównano sytuację osób ze wskazanej grupy wiekowej z sytuacją ogółu społeczeństwa w wieku produkcyjnym.

Stowa kluczowe: wiek niemobilny, metody taksonomiczne, porównanie krajów Unii Europejskiej. 